\title{
On the water hazards in the trans-boundary Kosi River basin
}

\author{
N. Sh. Chen ${ }^{1}$, G. Sh. Hu ${ }^{1,2}$, W. Deng ${ }^{1}$, N. Khanal ${ }^{3}$, Y. H. Zhu ${ }^{1,2}$, and D. Han ${ }^{4}$ \\ ${ }^{1}$ Key Lab of Mountain Hazards and Earth Surface Process, Institute of Mountain Hazards and Environment, \\ Chinese Academy of Sciences, Chengdu, China \\ ${ }^{2}$ Graduate School, Chinese Academy of Sciences, Beijing, China \\ ${ }^{3}$ Central Department of Geography, Tribhuvan University, Kathmandu, Nepal \\ ${ }^{4}$ Department of Civil Engineering, University of Bristol, Bristol, UK \\ Correspondence to: N. Sh. Chen (chennsh@imde.ac.cn)
}

Received: 3 September 2012 - Published in Nat. Hazards Earth Syst. Sci. Discuss.: Revised: 3 January 2013 - Accepted: 12 February 2013 - Published: 26 March 2013

\begin{abstract}
The Kosi River is an important tributary of the Ganges River, which passes through China, Nepal and India. With a basin area of $71500 \mathrm{~km}^{2}$, the Kosi River has the largest elevation drop in the world (from $8848 \mathrm{~m}$ of Mt Everest to $60 \mathrm{~m}$ of the Ganges Plain) and covers a broad spectrum of climate, soil, vegetation and socioeconomic zones. The basin suffers from multiple water related hazards including glacial lake outburst, debris flow, landslides, flooding, drought, soil erosion and sedimentation. This paper describes the characteristics of water hazards in the basin, based on the literature review and site investigation covering hydrology, meteorology, geology, geomorphology and socio-economics. Glacial lake outbursts are a huge threat to the local population in the region and they usually further trigger landslides and debris flows. Floods are usually a result of interaction between man-made hydraulic structures and the natural environment. Debris flows are widespread and occur in clusters. Droughts tend to last over long periods and affect vast areas. Rapid population increase, the decline of ecosystems and climate change could further exacerbate various hazards in the region. The paper has proposed a set of mitigating strategies and measures. It is an arduous challenge to implement them in practice. More investigations are needed to fill in the knowledge gaps.
\end{abstract}

\section{Introduction}

The Himalayan region is an important part of South Asia where water plays a crucial role. Ninety percent of water in the region is from three trans-boundary rivers, the Ganges
River (the most densely populated river system among all the five river systems in Asia), the Indus River and the Brahmaputra River. The three river basins include high mountainous areas and low-lying plains, covering parts of China, India, Nepal, Bangladesh, Pakistan, Bhutan and Afghanistan. The area of the region is $2750000 \mathrm{~km}^{2}$ with the length of $2750 \mathrm{~km}$ and width of $1000 \mathrm{~km}$. There are 660 million inhabitants in the region. In addition to a large population and scarce natural resources, water related disasters have been an important factor in contributing to the long-term poor economy, political disorder and inadequate education in the region (Reynolds, 1999; Ives, 1986; Ding and Liu, 1992). With climate change, the region's water hazards are expected to have even more impact on the local human lives and socioeconomic development.

As a representative river basin in the middle Himalaya, the Kosi River is a trans-boundary river across China, Nepal and India, and is also an important tributary to the River Ganges. The basin covers six geological and climatic belts, and has the main strata developed from the Quaternary System to the Proterozoic (Owen, 1995). The average discharge of the river is $1564 \mathrm{~m}^{3} \mathrm{~s}^{-1}$ (the Chatara hydrological station provide the data), and about $49 \times 10^{9} \mathrm{~m}^{3}$ of water flows into the Ganges River and merges into the Indian Ocean every year (Gleick, 2003). The population in the region consists of 15.3 million in 10 ethnic groups, and the number of inhabitants in the region is still increasing. According to the statistics in 2010, the annual population growth rates in the region were $2 \%$ in China, $2.24 \%$ in Nepal and $1.93 \%$ in India.

This trans-boundary river has a wide range of water hazards and as a case study, it is useful to understand the 


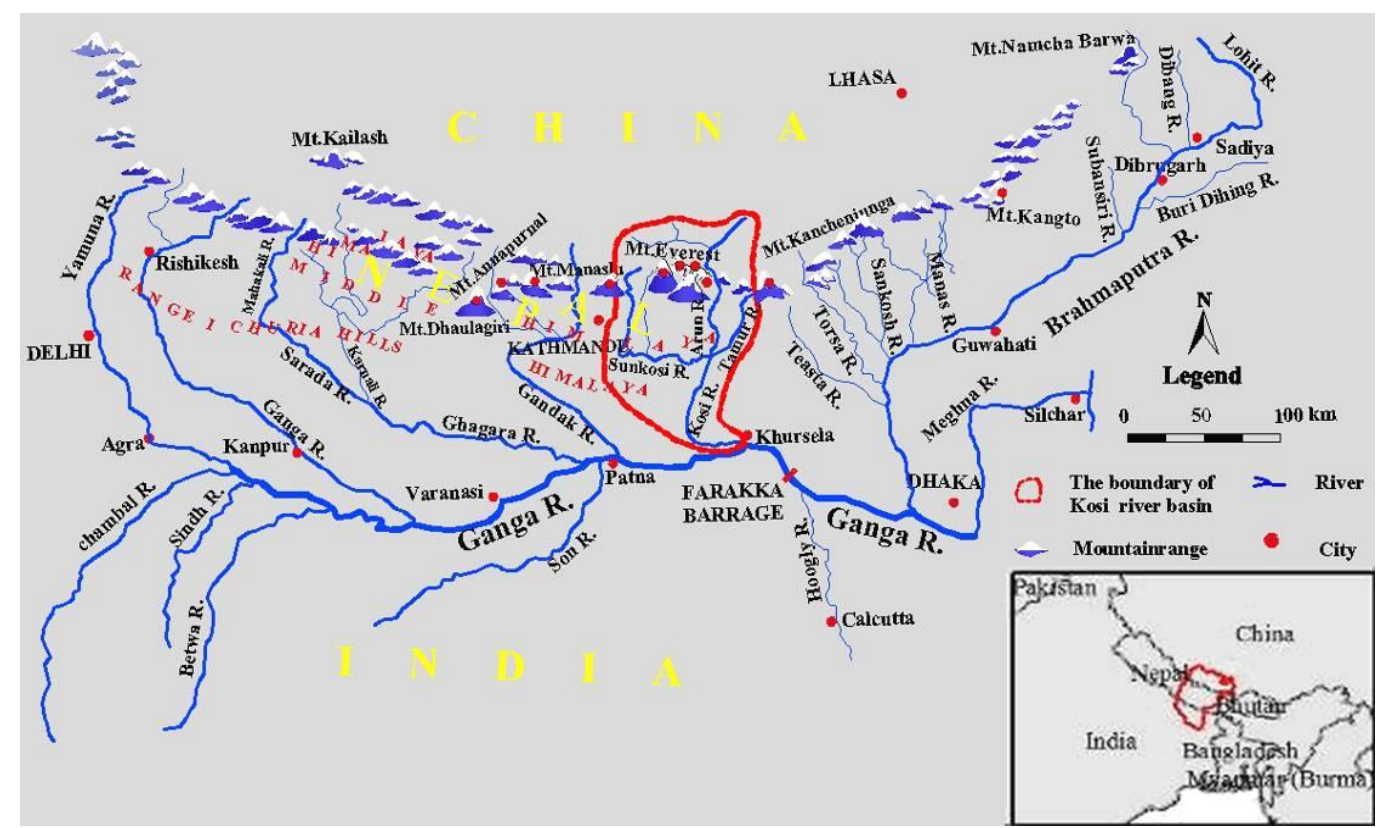

Fig. 1. The geographic location map of the Kosi River basin.

characteristics of multiple water hazards and explore potential mitigating measures. This paper describes a study based on literature review and a series of site investigations on this river basin. The site investigations for the Kosi River basin are determined based on the types and characteristics of water hazards: (1) glacial lake outbursts in the upstream of the river basin, in Tibet, China. Its influence scope is in the upper and middle stream of the river basin, especially in the boundary of China and Nepal. On the one hand, the site investigation is carried out along the glacial lakes in Tibet, China. On the other hand, it is carried out at the boundary of China and Nepal for the influence characteristics of outburst floods; (2) flood hazards, mainly in the middle and downstream of the river basin, in Nepal and India. For the sake of which, the site investigation of floods focuses on the two countries; (3) debris flows in the upper and middle stream of the river basin, especially in the boundary of China and Nepal. The selection for the site investigation is determined based on the types and distributions of debris flow in the river basin. There is more than one place of site investigations for each type; and (4) droughts in the middle and downstream of the river basin, in Nepal and India. Clearly, there are still many knowledge gaps in this challenging region and we hope this paper will stimulate more studies in this basin. The knowledge gained would be valuable for dealing with multiple water hazards in other similar trans-boundary river basins such as in the Andes, the Alps and the Rocky Mountains. This paper has proposed a set of mitigating strategies and measures in the end.

\section{Natural and socioeconomic characteristics of the Kosi Basin}

The Kosi River is an important river in the Himalayas and located in the middle of the region (Fig. 1). As a major tributary of the Ganges River (Rajiv and Sujit, 2009), it is the largest river in Nepal, and also one of the important transborder rivers in China. The river originates in the Himalayas with Mount Everest (the highest peak in the world) within its basin.

\subsection{River basin characteristics}

The river generally flows to the south, following the terrain of the Kosi River basin (however, the upstream tributaries are along the east-west directions due to Mt Everest). The length of the main river is $255 \mathrm{~km}$ with a drainage area of $71500 \mathrm{~km}^{2}$ (including $5770 \mathrm{~km}^{2}$ of glaciers). Within the total basin area, $28500 \mathrm{~km}^{2}$ is located in Tibet, $31600 \mathrm{~km}^{2}$ in Nepal, and $11400 \mathrm{~km}^{2}$ in India (Dixit, 2009).

The upstream is divided into three tributaries: the north branch is the main tributary named as Arun, the west branch as Sun Kosi and the east branch as Tamor. The three come together to form the Kosi River, near Dan Kute, which finally flows into the Ganges River in India (Birol and Das, 2010) (Fig. 2). The characteristics of the tributaries are in Table 1. The part of the Kosi River valley in India is an alluvial plain, an important part of the Ganges Plain. The part in Nepal has a great elevation drop of $8848 \mathrm{~m}$ (Mt Everest) to $60 \mathrm{~m}$. The part in China includes mainly the Pumqu and Poiqu rivers with the length and drainage area of $376 \mathrm{~km}$, and $25300 \mathrm{~km}^{2}$ 
Table 1. Characteristics of the tributary rivers.

\begin{tabular}{llrlll}
\hline No. & River & $\begin{array}{l}\text { Catch- } \\
\text { ment } \\
\text { area } \\
\left(\mathrm{km}^{2}\right)\end{array}$ & $\begin{array}{l}\text { Mean } \\
\text { discharge } \\
\text { discharge } \\
\left(\mathrm{m}^{3} \mathrm{~s}^{-1}\right)\end{array}$ & $\begin{array}{l}\text { Annual } \\
\text { sediment } \\
\text { load } \\
\left(10^{6} \mathrm{~m}^{3} \mathrm{~s}^{-1}\right)\end{array}$ & $\begin{array}{l}\text { Average } \\
\text { longitudinal } \\
\text { gradient } \\
(\%)\end{array}$ \\
\hline 1 & Sun Kosi & 18800 & 471 & 54.2 & 0.0062 \\
2 & Arun & 34300 & 451 & 34.6 & 0.0134 \\
3 & Tamor & 5800 & 347 & 29.6 & 0.0276 \\
\hline
\end{tabular}

for the former (Che et al., 2004) and $87 \mathrm{~km}$ and $2018 \mathrm{~km}^{2}$ for the latter (Chen et al., 2007).

\subsection{Topography}

The basin covers six geological and climatic belts: the Tibetan Plateau, the high Himalaya, the midland hills, the Mahabharat Lekh (range), the Chure (Siwalik range) and the Terai (Dixit, 2009). From the south to the north, the terrain generally ascends till Mt Everest and then descends (Fig. 3). The southern region with the altitude below $2000 \mathrm{~m}$ is named "Small Himalaya", and the bedrock is known as "Siwaliks". The area from the north of the Kosi River to Nyalam with the altitude between $2000 \mathrm{~m}$ and $3000 \mathrm{~m}$ is named as "Middle Himalaya". The area to the north of Nyalam with the altitude above $3000 \mathrm{~m}$ is called "Greater Himalaya". "Tibetan Himalaya" refers to the region north of Tingri. The precipitation in the Middle Himalaya area is the largest and starts to decline towards the Greater Himalaya (Burbank et al., 2003).

\subsection{Geology}

The geological structure in the region is very complex (Sinha et al., 2005) (Fig. 4). The southernmost Ganges Plain is made of the Quaternary deposits with a wide range of molasse and Siwalik gravels accumulated in the south of the lower Himalayas, which are subject to erosion from flash floods and thin debris flows. The rich gravel layers cover the areas of Sindhuli to Rajbas. There are widely developed schist and slate rocks in the lower south of the Himalayas, which are the source materials of debris flows and landslides in this arid area. Our recent field visit revealed a rich deposit of slates in an area from Kathmandu and Khuhot. In the north of the Middle Himalayas, there are widely distributed igneous and metamorphic rocks such as granite gneiss, granite amphibolite gneiss, migmatite, etc. In the Zhangmu-Nyalam area, along the left bank, there is abundant granite gneiss. In the middle of the High Himalayas, there are mainly hard rocks such as granite and granite gneiss. In the north, there is mainly a set of sedimentary rock deposits of slate and schist including sandstone and limestone. The Tibetan Himalayas have a large area of sedimentary rocks and a small area of metamorphic rocks. The area from Tingri to Mount Everest base camp has many soft rock layers of well developed slate and schist, etc. The regional structure from the northwest to

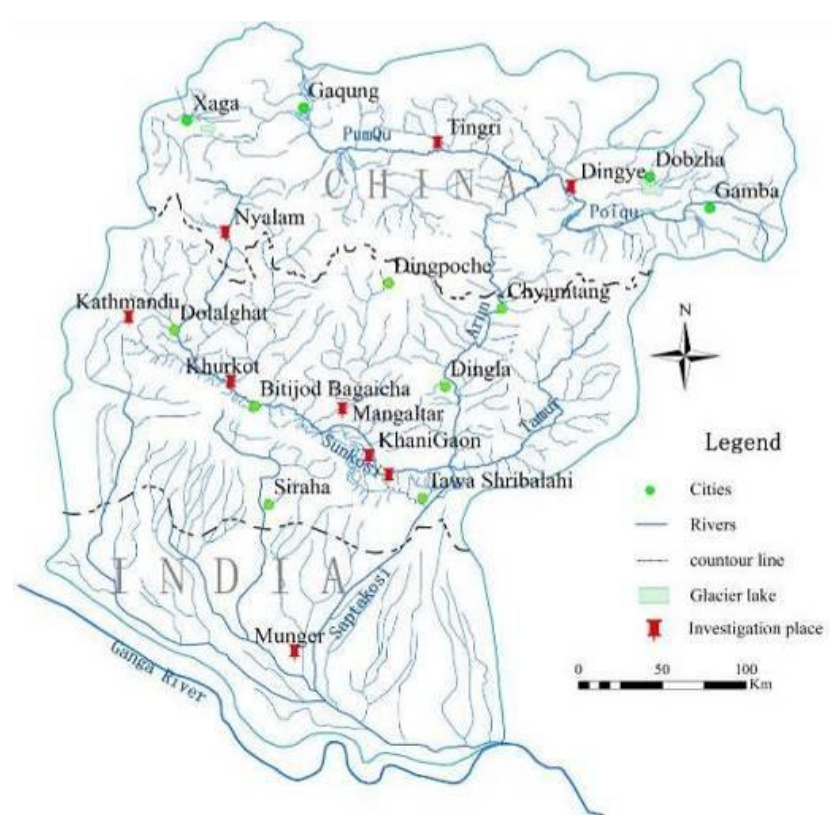

Fig. 2. Hydrographical network of the studied area.

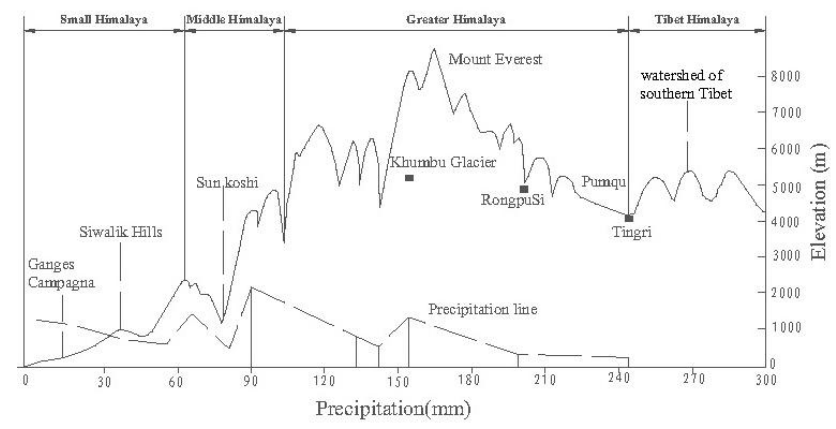

Fig. 3. The terrain profile of the Kosi River basin.

the southeast has three significant faults/sutures. The main boundary fault divides the thick layer of gravel deposits and metamorphic schist slate in the south side. The main central fault has promoted the hanging wall of granite to become the roof of world. The rocks on both sides of the Yarlung Zangbo suture zone have crushed against each other and suffered from severe weathering. The aforementioned geological features are depicted by the site visit photos in Fig. 5 .

\subsection{Climate, soil and vegetation}

The climate in the Kosi River basin ranges from the tropical south to the frigid north. The tropical zone covers the south of Janakpur-Barehachtera, the subtropical zone covers the surrounding area along the Sino-Nepal highway to Zhangmu, the temperate zone covers the areas along a line from Zhangmu to Nyalam, and the frigid zone covers the area above the Nyalam mountain pass. Precipitation is very unevenly distributed throughout the basin. The 


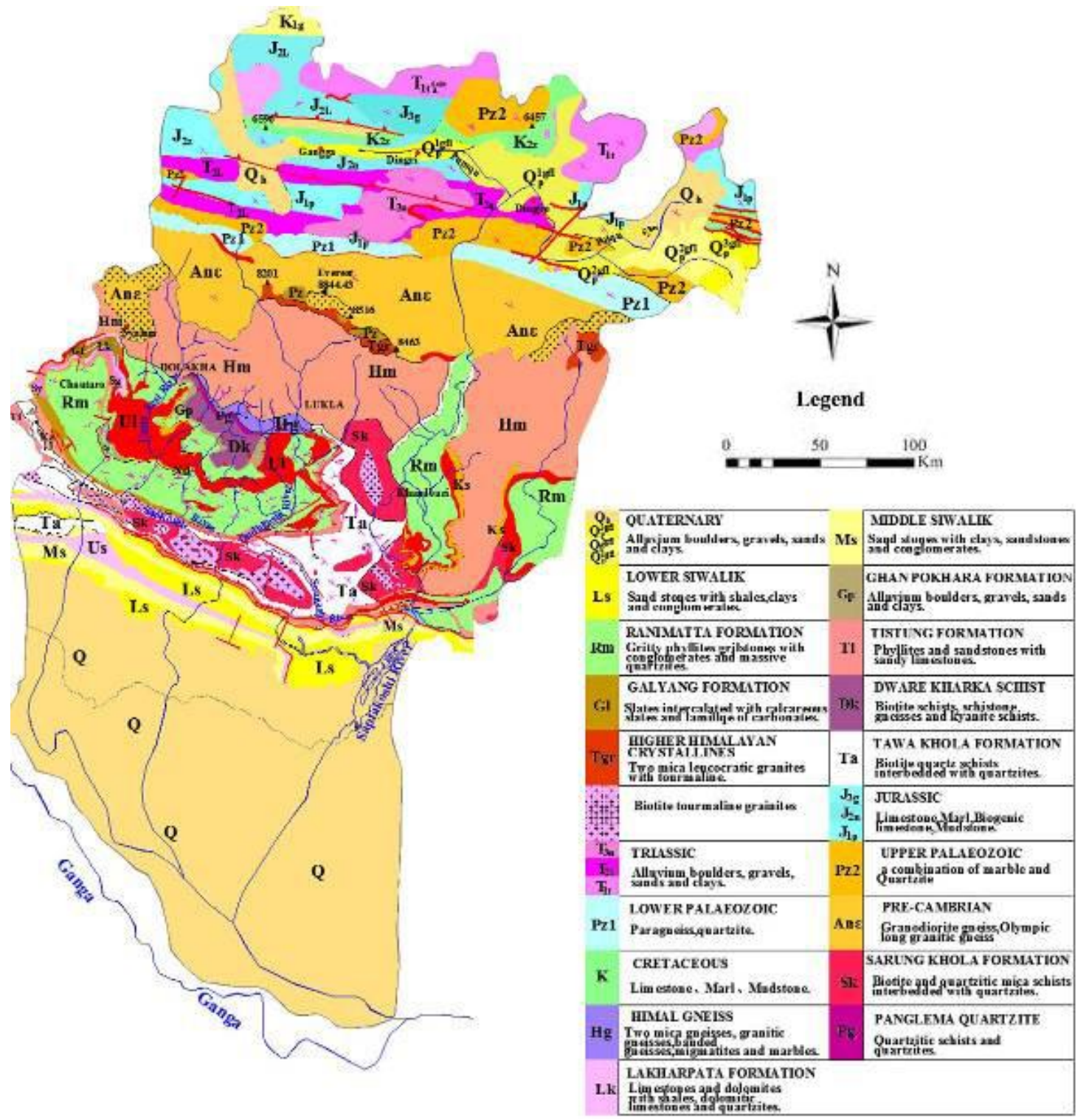

Fig. 4. The geological map of the Kosi River basin.

annual precipitation is about $300-400 \mathrm{~mm}$ in the northern Himalayan region, $1000-1500 \mathrm{~mm}$ in the subtropical and tropical region and $1500-2500 \mathrm{~mm}$ in the temperate region. Some parts of the basin have extremely high annual mean evapotranspiration (such as Sun Kosi, data was provided by Chatara hydrological station) and they suffer from frequent droughts and soil erosion. The temperate region has the best vegetation cover and a clear correlation between land elevation and precipitation, with the maximum precipitation at Zhangmu $2200 \mathrm{~m}$ a.s.l. Affected by the diverse climate and geology, the soils in the basin change from the alluvial soil and upland red loam to the yellow loam in Sun Kosi, then the yellow brown loam in Zhangmu-Nyalam, and the frigid desert soil at the region above $5000 \mathrm{~m}$. In correspondence with the soil and climate, vegetations in the basin change from the mixed forests of tropical/subtropical/temperate zones, to the shrub and grass land of the frigid region. The land is barren at the high frigid zone.

\subsection{Earthquake}

Seismic activities in the basin are frequent and the region is classified as an $8^{\circ}$ zone (Bilham et al., 2001). In the last two hundred years, there have been two major earthquakes with the magnitude greater than 8.0. The first one happened on 26 August 1833 at Shisha Pangma, west of Nyalam $\left(28.3^{\circ} \mathrm{N}\right.$, $85.5^{\circ} \mathrm{E}$ ), with a seismic intensity of $10^{\circ}$ and the second one occurred on 5 January 1934 at Dabanjia between Nepal and 

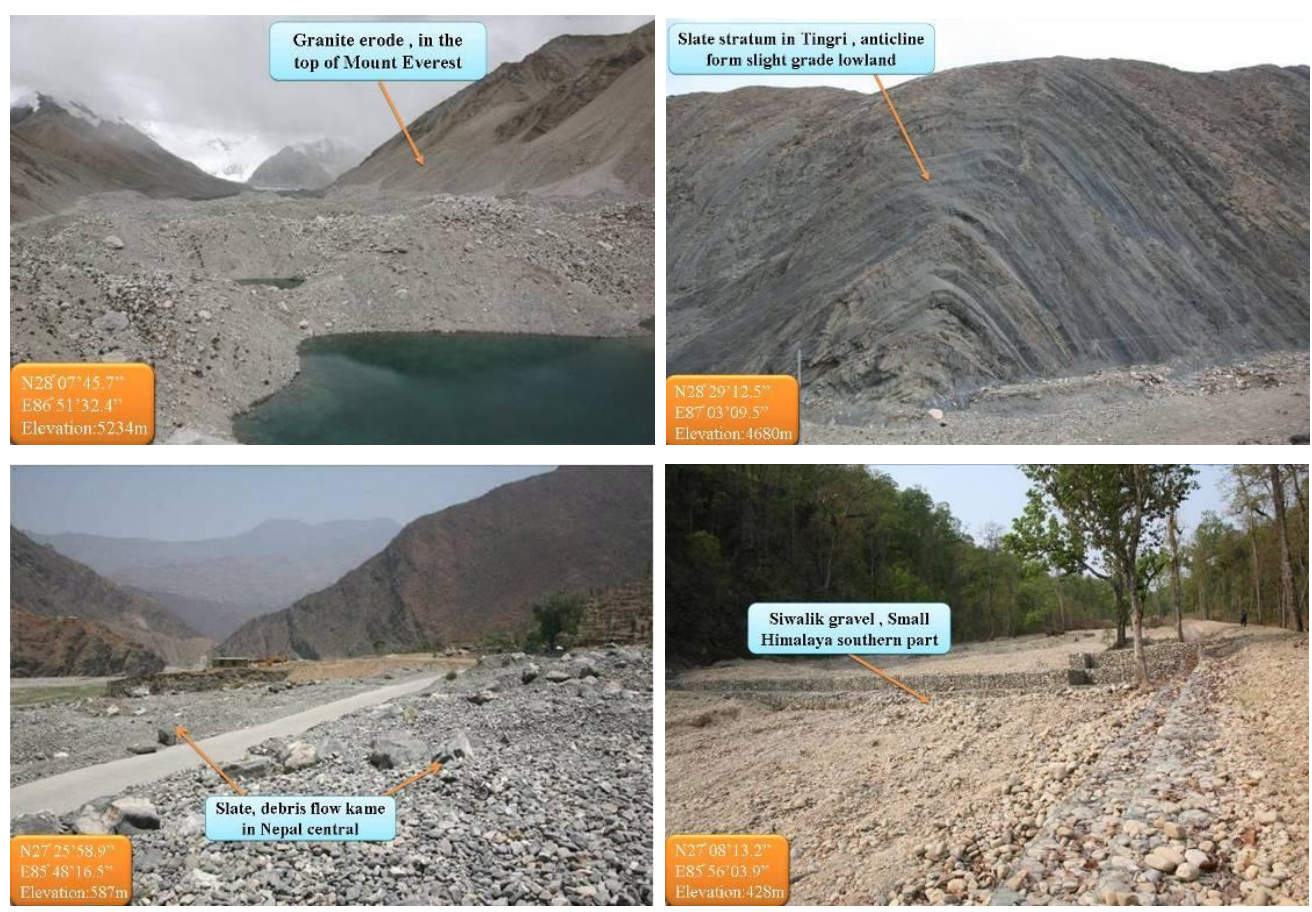

Fig. 5. The geological features from site visit photos in the Kosi River basin.

India $\left(26.5^{\circ} \mathrm{N}, 86.5^{\circ} \mathrm{E}\right)$. Moreover, a magnitude 7.0 earthquake occurred at Pulan $\left(30.2^{\circ} \mathrm{N}, 81.2^{\circ} \mathrm{E}\right)$ in October 1883 with a seismic intensity of $9^{\circ}$ and a magnitude 6.25 earthquake occurred at Tingri $\left(28.0^{\circ} \mathrm{N}, 92.5^{\circ} \mathrm{E}\right)$ on 17 June 1834 with a seismic intensity of $8^{\circ}$.

\subsection{Socioeconomic conditions}

The basin has an area of $71500 \mathrm{~km}^{2}$ and a population of 15.3 million (2009). The total annual GDP was about USD \$ 10.4 billion in 2009 (i.e. less than USD \$ 700 per capita year ${ }^{-1}$ ). The region in India is mostly alluvial with subtropical climate and is very productive in agriculture. However, due to its large population (about 1000 people per $\mathrm{km}^{2}$ ), the average income in the region is below the national average of India (USD\$ 1134 in 2009). The Nepalese in the region are about 6 million (1/4 of the country's population). The population density is $200 \mathrm{~km}^{-2}$ varying from 32 (Solukhumbu) to 276 (Kavre) in the central part of the Kosi River. Forty percent of the residents are below Nepal's poverty line (higher than the national average of $30 \%$ ), but the GDP per capita in the region is near to Nepal's national average (USD \$ 427). The population in China's territory is 94 thousand (with an average population density of $3.2 \mathrm{~km}^{-2}$ varying between 1.9 and $5.5 \mathrm{~km}^{-2}$ ). The average GDP per capita of Chinese in the region is USD\$ 1970. Clearly, the region in the middle of the basin has the worst economic condition. The population density increases rapidly from the upstream to downstream.

\section{The characteristic of water related hazards}

Water related hazards in the Kosi River basin include glacial lake outburst, debris flow, landslides, flooding, drought, soil erosion and sedimentation. They are characterized by high frequencies, great impact areas, long durations and close interactions with each other.

\subsection{Glacial lake outburst}

The glacial lake outbursts frequently happen at high altitude and high-latitude areas, such as Canada (the Ekalugad Valley 1967 from Church, 1972, and the Hazard Lake 1978 from Clarke, 1982), USA (Lake George 1958 from Stone, 1963), Switzerland (Gomer 1944 from Haeberli, 1983), Norway (Demmevatan 1937 from Clague and Mathews, 1973, and Strupvatnet Lake 1969 from Whalley, 1971) and Iceland (Graenalon 1939 from Thorarinsson and Sigurdur, 1939, and Gjanupsvatn 1951 from Arnborg, 1955). The south slope of the Himalayas is one of areas where glacial lakes burst out frequently (Reynolds, 1995). There have been 33 recorded disasters resulting from glacial lake and dammed-lake outbursts in the region (Liu and Sharma, 1988; Richardson and Reynolds, 2000), over the half of which were concentrated in the upper Kosi River basin. The glacial lake outbursts in the region deserve further studies due to their high frequency and impact.

Fast glacier retreat during the past decade has resulted in the rapid accumulation of meltwater in most of the 
Table 2. Historical GLOFs in the Kosi River basin.

\begin{tabular}{|c|c|c|c|c|}
\hline No. & Lake & Date & $\begin{array}{l}\text { Volume/peak flow } \\
\left(10^{6} \mathrm{~m}^{3} / \mathrm{m}^{3} \mathrm{~s}^{-1}\right)\end{array}$ & Summary of devastation \\
\hline 1 & Tarraco, Nyalam, China & 1935.8.28 & $6.3 /-$ & Flooded $66700 \mathrm{~m}^{2}$ of wheat fields. \\
\hline 2 & Qiongbixiamaco, Yadong,China & 1940.7.10 & $-1-$ & Flood, debris flow. \\
\hline 3 & Gelhaipco, Dingye, China & 1964.9.21 & $23.4 / 4500$ & Damaged Nepal-China Highway, 12 trucks, etc. \\
\hline 4 & Longdaco, Jielong, China & 1964.8.25 & $-/ 1000$ & Flood, debris flow. \\
\hline 5 & Ayacuo, Tingri, China & 1968.8.17 & $-1-$ & - \\
\hline 6 & Ayacuo, Tingri, China & 1969.8.17 & $-1-$ & - \\
\hline 7 & Ayacuo, Tingri, China & 1970.8.18 & $90 /-$ & Damaged roads and bridge up to $40 \mathrm{~km}$ away. \\
\hline 8 & Zhangzangbo, Nyalam, China & 1964 & $-1-$ & \\
\hline 9 & Zhangzangbo, Nyalam, China & 1981.7.11 & $19 / 1600$ & $\begin{array}{l}\text { Destroyed bridge, highway, hydropower } \\
\text { station, farmland, } 200 \text { deaths. }\end{array}$ \\
\hline 10 & Yindapuco, Dingye, China & 1982.8.27 & $12.8 /-$ & $\begin{array}{l}\text { Devastated } 8 \text { villages and farmland, } \\
\text { killed } 1600 \text { livestock. }\end{array}$ \\
\hline 11 & Jialong lake, Nyalam, China & 2002.5 .23 & $-1-$ & - \\
\hline 12 & Jialong lake, Nyalam, China & 2002.6.29 & $-/ 2.36 \times 10^{7}$ & $\begin{array}{l}\text { Destroyed bridge, economic loss amounts to } \\
3.05 \text { million RMB . }\end{array}$ \\
\hline 13 & Phucan, Tamur Khola, Nepal & 1980 & $-1-$ & $\begin{array}{l}\text { Water level raised by } 20 \mathrm{~m} \text {. Including heavy } \\
\text { debris of large rocks, etc. Damaged forest, } \\
\text { river bed, etc. }\end{array}$ \\
\hline 14 & Jinco, Arun River, Nepal & 1985.8.27 & $-1-$ & $\begin{array}{l}\text { Damaged eight villages, livestock, farm land, } \\
\text { roads, bridges, etc. }\end{array}$ \\
\hline 15 & Nare Drangka, Dudh Kosi River, Nepal & 1977.9.3 & $-1-$ & $\begin{array}{l}\text { Damaged mini-hydro plant, roads, bridges, } \\
\text { cultivation fields, etc. }\end{array}$ \\
\hline 16 & Dig Tsho, Dudh Kosi River, Nepal & 1985.8.4 & $-/ 2000$ & $\begin{array}{l}\text { Destroyed Namche hydropower plant } \\
\text { completely, damaged roads, bridges, farm land, } \\
\text { livestock, houses, inhabitants. }\end{array}$ \\
\hline 17 & Chubung, Dudh Kosi River, Nepal & 1997.7 & $-1-$ & $\begin{array}{l}\text { Damaged houses, cultivation field at } \\
\text { Beding village. }\end{array}$ \\
\hline
\end{tabular}

moraine-dammed lakes in the basin, has increased their potential energy and reduced the shear strength of the damming material. Ultimately the loose-moraine dam will be breached, causing a glacial lake outburst flood (GLOF) (Ives, 1986; Richardson and Reynolds, 2000). During the past decade, Himalayan glaciers have generally been shrinking and retreating faster while moraine-dammed lakes have been proliferating. Although the number of lakes above $3500 \mathrm{~m}$ a.s.l. has decreased, the overall area of moraine-dammed lakes is increasing (Bajracharya and Mool, 2009), i.e. glaciers in the Mt Everest (Sagamartha) region, Nepal, are retreating at an average rate of 10-59 $\mathrm{ma}^{-1}$. From 1976 to 2000, the Lumding and Imja Glaciers retreated 42 and $34 \mathrm{ma}^{-1}$, respectively, a rate that increased to $74 \mathrm{ma}^{-1}$ for both glaciers from 2000 to 2007 (Bajracharya and Mool, 2009).

\subsubsection{Frequent outbursts}

Relative to many other natural hazards, the glacial lake outburst is less frequent but has more serious impacts. Based on the observation records, there have been 17 large-scale glacial lake outbursts in the Kosi River basin (Mool, 1995; Yamaba and Sharma, 1993) (Table 2). There was an additional potential glacial lake outburst, but it was discovered earlier and mitigated by human interventions (Liu, 2006). However, most of them were undiscovered and caused significant losses to the downstream areas, such as the Cirenmaco glacial lake outburst at Poiqu, 11 July 1981; Galongco glacial lake outburst, northwest of Nyalam County Xigaze region, 23 May and 29 June 2002; the Tarraco glacial lake outburst, in Nyalam County 28 August 1935; and Ayacuo glacial lake outburst in Tingri County, 17 August 1968 and 1969, and 18 August 1970. Among them, the most severe ones are Tarraco glacial lake outburst (28 August 1935) in Nyalam County and Zhangzangbo glacial lake outburst in 1964 and 1981 (Lü et al., 1999).

Although the Kosi River basin is $2.6 \%$ of the the southern slope region of the Himalayas (2.75 million $\mathrm{km}^{2}$ ), $51.6 \%$ of glacial lake outbursts over the whole region occurred in the Kosi River basin. In China, the area of the Kosi River basin is $28500 \mathrm{~km}^{2}$ ( $2.4 \%$ of Tibet of 1.22 million $\mathrm{km}^{2}$ ), but $66.6 \%$ of glacial lake outbursts occurred in the river basin (12 out of 18) (Liu, 2006; Fan et al., 2006).

\subsubsection{The extreme discharge}

The discharges from glacial lake outbursts in the Kosi River basin are extremely large and can reach over 100 times of the 
normal discharge (Xu, 1985). The outburst impact areas are widespread and could reach to the third tributaries. For example, the summer mean runoff at the Zhangzangbo River is $100 \mathrm{~m}^{3} \mathrm{~s}^{-1}$ (at Zhangmu Port). The maximum runoff caused by the Zhangzangbo glacial lake outburst in 1981 reached $16000 \mathrm{~m}^{3} \mathrm{~s}^{-1}, 160$ times greater than its mean runoff $(\mathrm{Xu}$, 1985). Apart from the entire Zhangzangbo River basin, the disaster area was distributed mainly in the Boiqu River basin, which is a higher basin than the Zhangzangbo River basin. The China-Nepal highway and its related infrastructure were severely damaged.

\subsubsection{Severe consequence}

Glacial lake outbursts in the Kosi River basin can lead to serious trans-boundary disasters. For example, the Zhangzangbo glacial lake outburst in 1981, with 200 deaths, destroyed the Sun kosi hydropower plant in Nepal. Many villages and roads along the river within the length of $60 \mathrm{~km}$ were severely damaged (Fig. 6). The direct economic losses were estimated at USD $\$ 156$ million, and the indirect economic losses were at USD \$ 300 million. The total economic losses were at USD \$ 456, equivalent to $20 \%$ of Nepal's national revenues (Meon and Schwahz, 1992).

\subsubsection{Cascading debris flows and landslide hazards}

Since the massive floods triggered by glacial lake outbursts usually occur in highlands above $5000 \mathrm{~m}$, those floods could seriously erode the slopes of the Greater Himalaya and Middle Himalaya. They could also trigger debris flows and massive landslides. For example, at Quxam-Friendship bridge (Nyalam), a large number of traction type landslides (707 times) were induced since the Zhangzangbo glacial lake outburst in 1981.

\subsection{River floods}

The Kosi River basin suffers from frequent floods and in the last $60 \mathrm{yr}$, Nepal has been affected by 10 large scale floods from the Kosi (Dixit, 2009) and a similar number of major floods also occurred in India (Bhalme and Mooley, 1980). These floods have caused severe sedimentation problems.

These floods are a result of human-nature interaction. On one hand, the frequent rainstorms in the river basin lead to the increase of floods directly. On the other hand, there are communication problems in the management of hydraulic engineering facilities. Due to a lack of shared information of early warning between the upper and downstream countries, information on the floods occurring in the upstream fails to be passed on to downstream communities, so insufficient warning is issued for any pre-emptive actions to operate hydraulic structures for flood defence.

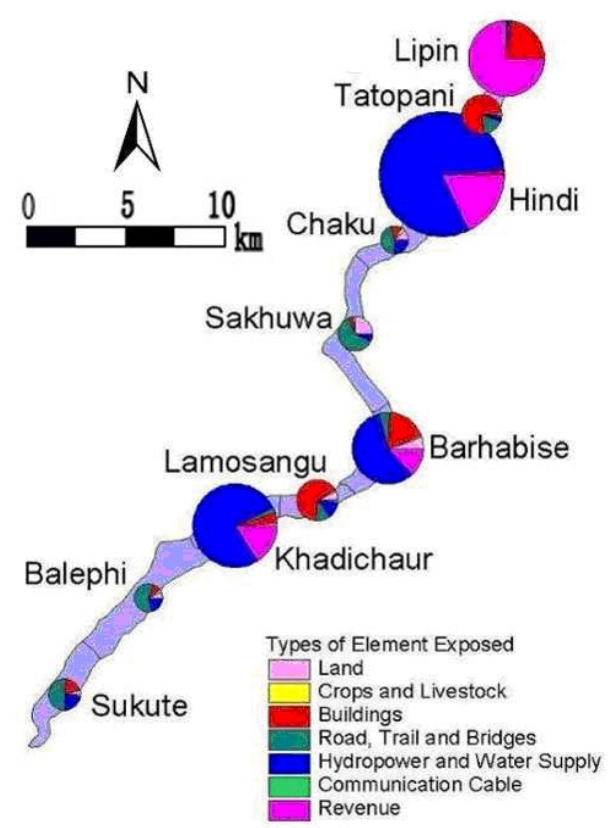

Fig. 6. Estimated amounts at risk with flood level, same as in 1981 GLOF.

\subsubsection{Flood and sedimentation}

The Kosi River basin is highly erodible and its erosion modulus is $3420 \mathrm{t} \mathrm{km}^{-2} \mathrm{a}^{-1}$ (the sediment density is calculated by $1.8 \mathrm{~g} \mathrm{~cm}^{-3}$ based on the field investigated data), the erosion modulus is greater than the main stream of the Yellow River in China whose erosion modulus is around $2330 \mathrm{t} \mathrm{km}^{-2} \mathrm{a}^{-1}$ (Ran et al., 2004). A recent flood, on 18 August 2008, caused 1-2 $\mathrm{m}$ of sediment deposition (Rashmi et al., 2010). The Kosi River transports 120 million $\mathrm{m}^{3}$ of sediment per year into the downstream and its river mouth has moved westward by $115 \mathrm{~km}$ in the past $220 \mathrm{yr}$ (Yamada, 1991).

\subsubsection{Floods risk management}

The flood damage usually occurs in the middle and lower reaches. Although the river dykes and many hydraulic structures (such as sluice gates) along the river are designed and constructed to stand once in 100-yr frequency floods, their effective management has not been achieved. The flood embankment is above $4 \mathrm{~m}$ and the channel width is more than $1000 \mathrm{~m}$. Based on a simple estimation, such a channel should be able to cope with a flood discharge up to $12000 \mathrm{~m}^{3} \mathrm{~s}^{-1}$ (the average water speed is $3 \mathrm{~m} \mathrm{~s}^{-1}$ based on the field investigation, $27^{\circ} 28^{\prime} 45^{\prime \prime} \mathrm{N}, 85^{\circ} 44^{\prime} 11^{\prime \prime} \mathrm{E}$ ). However, a flood of 50 -yr frequency broke out at the border between Nepal and India on 18 August 2008 (Ramaswamy, 2008). As a result, 2.1 million people were affected with 42 dead and 150 missing, and $650 \mathrm{~km}^{2}$ of land were flooded. One of the main reasons for this severe flood damage was that the downstream sluice gates were not opened earlier enough to discharge the 


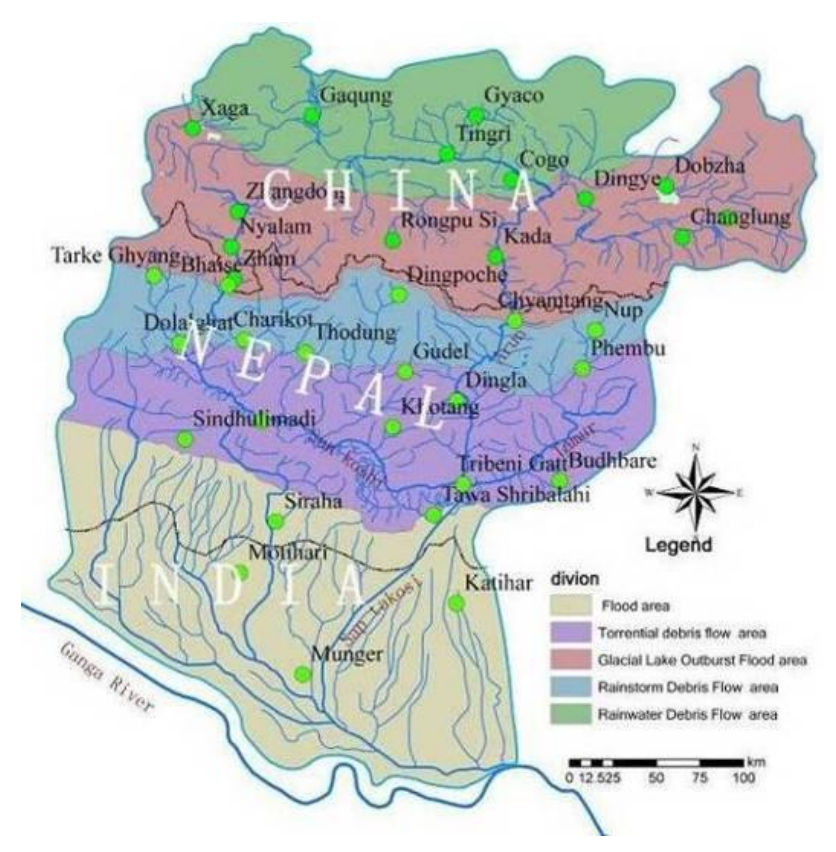

Fig. 7. The regionalization of debris flow types in the study area.

flood water since no information was shared between the upstream and downstream countries.

\subsection{Debris flow}

Debris flows in the Kosi River basin can be classified into four types (Fig. 7). Tibetan Himalayas is extremely dry and its physical weathering is very intense. Small-scale rainfall triggered debris flows are common. In the high lands, the GLOF debris flows are triggered by glacial lake outbursts, but they occur infrequently. In the middle of the basin, rainstorm debris flows are widely distributed. In this area, there are rich loose materials from metamorphite slate, schist and phyllite. These metamorphites offer a large amount of solid materials for the debris flow. In the meantime, summer rainstorms are highly concentrated from June to August (over $70 \%$ of the annual precipitation). In addition, the dry soils are highly collapsible and changeable under the action of rainfall, which could trigger the outbreak of geotechnical mudslides easily. There are more torrent debris flows in the Small Himalayas.

The rainfall flood-debris flows, in Tibetan Himalayan, concentrate along the Sino-Nepal highway. Figure 8 illustrates the Menbudui gully debris flow field investigation $\left(28^{\circ} 44^{\prime} 56.0^{\prime \prime} \mathrm{N}, 86^{\circ} 09^{\prime} 38.3^{\prime \prime} \mathrm{E}\right)$. The area of the gully is $2.3 \mathrm{~km}^{2}$ and the elevation drop is $450 \mathrm{~m}(5134-4684 \mathrm{~m})$. The bedrock of the gully is $\mathrm{J}_{3 \mathrm{~m}}$ slate and metamorphose stratum. In the debris flow deposit, the gravels with more than $2 \mathrm{~mm}$ sizes are $62 \%$, the sands of $0.05-2 \mathrm{~mm}$ are $24 \%$, the powder grains of $0.01-0.05 \mathrm{~mm}$ are $3 \%$, and the clay particles with less than $0.005 \mathrm{~mm}$ is $6 \%$. There are 1.25 million $\mathrm{m}^{3}$ of loose solid materials in the investigated site and they occupy

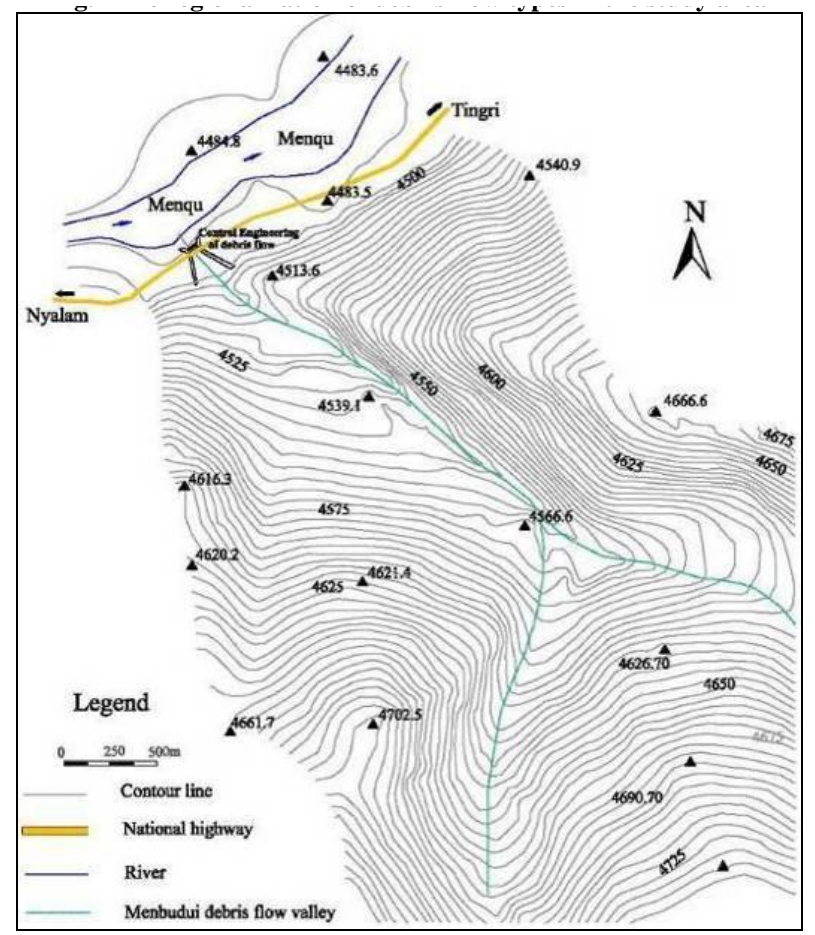

Fig. 8. The terrain map of Menbudui gully along the Sino-Nepal highway.

$5.3 \%$ of the whole area. The gully has $1-2$ debris flows every summer. The debris flow alluvial fan covers an area of $875 \mathrm{~m}^{2}$. The accumulated materials of each debris flow event are estimated at several hundred thousands of cubic meters. Engineering measures such as barrages and platoon guides are effective tools to protect the highway from debris flow damages.

The Zhangzangbo debris flows are a type of the Himalayan glacial lake outburst debris flows located at Nyalam County, on the southern slope of Himalayas. At 10:30 LT on 11 July 1981, the Cirenmacuo glacial lake burst and eroded the loose solid materials along the way to form a loose debris flow. The Zhangzangbo ditch $\left(28^{\circ} 04^{\prime} 46.2^{\prime \prime} \mathrm{N}, 85^{\circ} 59^{\prime} 59.7^{\prime \prime} \mathrm{E}\right.$, and its outlet altitude at $3259 \mathrm{~m}$ ) was a tributary of the River Boqu with an $8.5 \mathrm{~km}$ long channel and a drainage area of $50.5 \mathrm{~km}^{2}$ in a broad-leaved form (Fig. 9). The highest point of the catchment is $6109 \mathrm{~m}$ and the outlet attitude to the Boqu River is $3168 \mathrm{~m}$ with a relative relief of $2941 \mathrm{~m}$. The glaciers and permanent snow covered an area of $27.7 \mathrm{~km}^{2}$ ( $45.15 \%$ of the catchment). The average slope of the hillside above the road is $>40^{\circ}$. At an altitude of $3550 \mathrm{~m}$ above the valley, including seven major tributaries, the vertical channel gradient is large, about $149.6 \%$ - $478.9 \%$ o. There are many high mountains, deep valleys and steep slopes in the Zhangzangbo catchment. The exposed strata are Presinian Kornhill Bridge Group (AnZk) with quartz mica schist, biotite gneiss, and gravel of Quaternary slope deposits from 


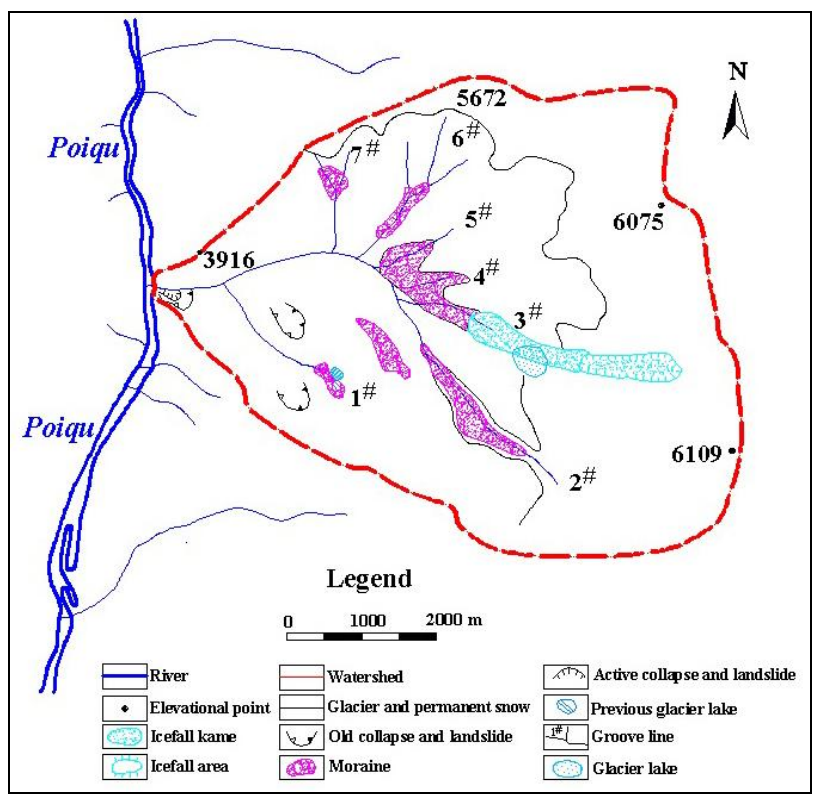

Fig. 9. The basin characteristic map of the Zhangzangbo debris flow gully.

soil residual. Landslides and avalanches are widespread. The Zhangzangbo gully moraine platforms are widely distributed on both sides. The modern glacier tongue and front surface are covered by lateral moraine and end moraine. Before the 1981 outburst, the Cirenmacuo glacial lake was located in the branch gully $3 \#$ of the Zhangzangbo ditch with its water levels between $4640-4690 \mathrm{~m}$. The glacial lake was $1.5 \mathrm{~km}$ long with an area of $0.643 \mathrm{~km}^{2}$. The water storage capacity was only $2 \times 10^{7} \mathrm{~m}^{3}$. Since this debris flow, 707 landslides have occurred and more are expected in the future. The roads in the area are frequently blocked during the rainy seasons.

The arid valley of the middle Kosi River mainly suffers from rainstorm debris flows. A typical example is located at the Khurkot debris flow gully (Fig. 10). The basin area of the gully is $3.8 \mathrm{~km}^{2}$. There have been a large number of landslides in the middle-upstream of the gully. In the past, the debris flow activities had led the river to change its courses. In a midnight of July 1985, the gully experienced a debris flow causing eight deaths. The maximum debris flow boulder reached $4.8 \mathrm{~m} \times 2.4 \mathrm{~m} \times 1.9 \mathrm{~m}$. The flood and debris flow lasted for 3-4 days. The debris flow contained a lot of stones, wood and roots. The debris flow speed is equivalent to people's running speed. According to the clay content analysis measured in the debris samples, the debris flow density was about $1.8-1.6 \mathrm{~g} \mathrm{~cm}^{-3}$. The peak flow in the measurement section was $80-100 \mathrm{~m}^{3} \mathrm{~s}^{-1}$ and the velocity reached 5$6 \mathrm{~m} \mathrm{~s}^{-1}$. The accumulated debris volume reached $30000 \mathrm{~m}^{3}$.

In the Small Himalayas, debris flows caused by torrents are quite common. They often threaten roads, farmlands, residential areas and other infrastructures and lead to the damage of forest along the way. Mitigating engineering measures
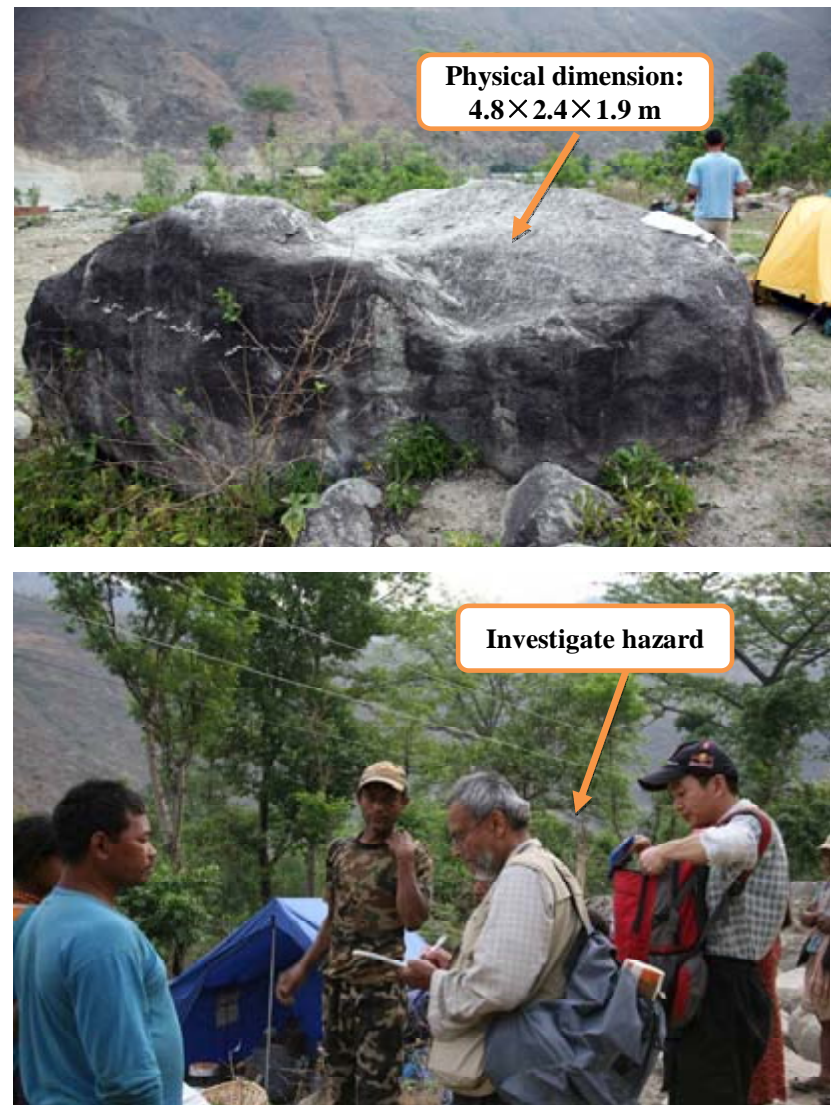

Fig. 10. Field investigation of Khurkot debris flow gully.

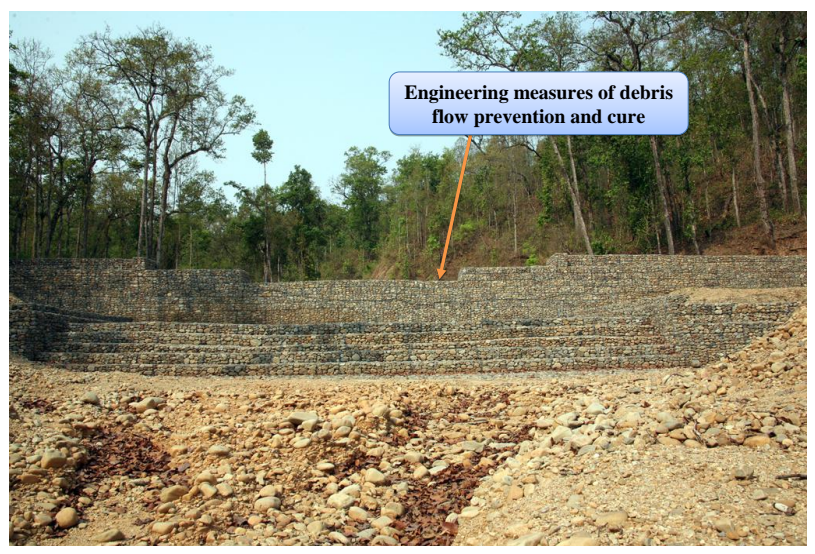

Fig. 11. The control engineering in Nepal.

include stone walls with barbed wire and trap dams combined with diversion channels (Fig. 11). The photos were taken at the investigation site: $27^{\circ} 08^{\prime} 13.2^{\prime \prime} \mathrm{N}, 85^{\circ} 56^{\prime} 03.9^{\prime \prime} \mathrm{E}$ and altitude of $428 \mathrm{~m}$. 


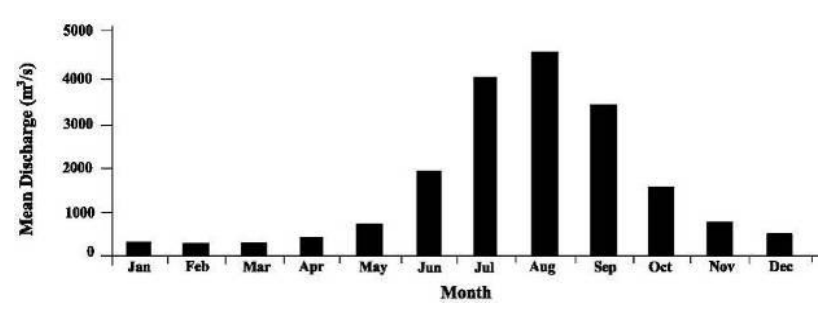

Fig. 12. Monthly distribution of the Kosi River mean discharge (the Chatara gauge station).

\subsection{Drought}

The Kosi River basin has a severe drought problem characterized by vast affected areas and interrupted human activities. The drought mainly affects the middle Kosi River basin, the Tibetan Himalayas and the downstream plain. In the Indian region alone, there were 11 large-scale droughts during a $70 \mathrm{yr}$ period (1905-1975) with serious losses in human lives and properties (Bhalme and Mooley, 1980). In Nepal, major droughts occur once every 2-3 yr (Sharma, 1979).

The middle Kosi River basin's annual mean evapotranspiration is about $1500 \mathrm{~mm}$ to $2000 \mathrm{~mm}$. However, the annual mean precipitation in the area is only about $900-1200 \mathrm{~mm}$ (data was provided by Chatara hydrological station). Therefore, the region is hydrologically short of water. In addition, the seasonal distribution of precipitation is very uneven with $70 \%$ in the summer months from June to August (Fig. 12). The vegetation cover is less than $60 \%$. The regional human population has significantly expanded and $30 \%$ of the arable lands are located in hilly slope lands with more than $15^{\circ}$ in slope gradients. There is a severe shortage of hydraulic engineering facilities to store and regulate water supply. All those factors jointly exacerbate the drought problem. In the future, global climate change has a potential to amplify the existing drought situations (Xue et al., 2009).

A field visit to a village located at the middle and lower reaches of Nepal Jhigu $\left(27^{\circ} 37^{\prime} 50.5^{\prime \prime} \mathrm{N}, 85^{\circ} 38^{\prime} 26.5^{\prime \prime} \mathrm{E}\right.$ with elevation $830 \mathrm{~m}$ ) demonstrated a typical example in the drought region (Fig. 13). In 1972, a new highway was constructed and there was an economic boom in the surrounding area. More population moved in and commercial crops such as mango, papaya and others were widely planted. Forested lands were destroyed (from 70-80\% dropped to 40-50\%) and soil erosion was very serious. During the drought season, lowland residents need to excavate ditches in the river bed to get water. The residents on the hillslopes need to drill wells at least $20 \mathrm{~m}$ deep. For the residents on the high land, the wells have to be $74 \mathrm{~m}$ deep. During our site visit, more than $90 \%$ of the rivers were totally dry. The farm lands in the region are mainly rain fed and only $10 \%$ of them are irrigated. There are massive glacier retreats in the Tibetan Himalayas. Since the annual precipitation in the area is only
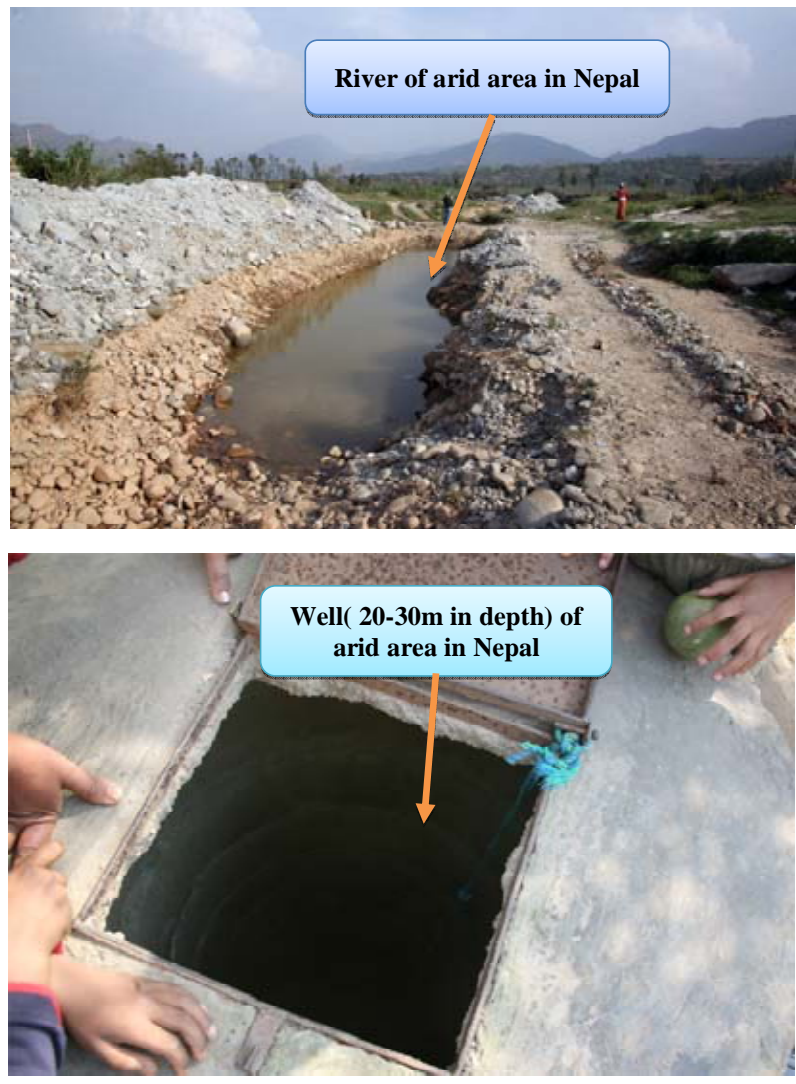

Fig. 13. Site visit to the drought region in Nepal.

about $300-400 \mathrm{~mm}$, many lakes are shrinking. The Peigucuo lake has shrunk by 5-6 meters every year since 2006 .

\section{Mitigating strategies and measures}

Clearly, there are urgent demands for mitigating strategies and measures to tackle the water hazards in the Himalayas. The existing strategies and measures are as follows (Bajracharya and Mool, 2009; Mool et al., 2001; Dixit, 2009): (1) monitoring - key indicators, including changes in the lakes and their impoundments, which should be observed using different data sets at varying time scales to evaluate glacier hazard and stability of moraine dams; (2) early warning - provision of timely and effective information, through identified institutions, that allows individuals exposed to imminent hazards to take action to avoid or reduce their risk and prepare for effective response; (3) mitigation - measures to mitigate hazard risks by structural and non-structural means; (4) awareness raising - education to raise local awareness, and increase the relevant knowledge about how to respond; and (5) community participation and institutional arrangement.

Although the existing strategies and measures are very valuable for dealing with water hazards in the Himalayas, there are still many shortages in them. For example, the 
current monitoring and early warning systems cannot share the relevant information between upstream and downstream areas. An effective cooperative management model in the basin is needed. The scales and modelling tools of structural and non-structural measures should be different according to the different types of water hazards. For example, it should mainly take preventive and non-structural measures to mitigate the glacial lake outburst. For the drought, small terraced reservoirs and composite hydraulic structures should be used to provide power, irrigation and water supply, and so on. In this study, we found that the existing studies on strategies and measures were focused on a limited area (e.g. a country or a town) and one or two types of water hazards (Richardson and Reynolds, 2000; Shroder Jr., 1989). Since systemic and comprehensive studies are rare in the region, we propose the following mitigating strategies and measures to tackle various types of water hazards for this trans-boundary river basin.

\subsection{Mitigating strategies}

The Kosi River is a typical river among many trans-boundary rivers in the Himalayas. However, little research has been carried out in the region and scientific and technological support on mitigating natural hazards is lacking. There is an urgent need to deal with the natural hazards in order to protect local residents and promote sustainable development in the region. We propose the following strategies (summarized in Fig. 14).

\subsubsection{International collaboration}

The Kosi River runs through three nations (China, Nepal, and India). It is important to collect and share the relevant information across the nations in meteorology, hydrology, geology, ecology and socioeconomic conditions. Collaborative scientific research is needed to explore and understand the characteristics of water related hazards. An integrated information database should be established so as to be shared among the countries concerned and the international research community. Water resources management should be coordinated among the countries in order to minimize the potential conflicts and maximize the common benefits. Measures should be taken to control the rapid population increase in the region. The harmony between humans and natural resources should be promoted.

\subsubsection{Integrated water resources management and hazard mitigation}

Joint intergovernmental policies on water resources and hazard mitigation should be established. Flood water may be turned into water resources if there are sufficient water storage facilities. For a start, it may be useful to set up a demonstration area to test and implement such policies (e.g. the Poiqu-Sun Kosi area) so that valuable experience and lessons could be learned. With the accumulated knowledge gained, it may be possible to apply the improved policies to other parts of the basin.

\subsubsection{Interdisciplinary measures}

Biological engineering measures for ecological restoration are ideal long term solutions. However, they should be complemented by other engineering measures since the Kosi River basin suffers from very uneven water distribution, poor vegetation cover, and inefficient water resources utilization that prevent the bio-engineering measures to take full effect. In addition, non-engineering measures such as hazard early warning systems should be developed. A systematic monitoring system should be built with appropriately sited meteorological and hydrological stations in the region. Satellite and numerical weather models can also provide valuable warning information. Effective warning dissemination channels should be established.

\subsubsection{Cascading hazard control}

Glacial lake outbursts are able to trigger debris flows and floods. They will in turn cause severe erosion along the downstream river banks. Erosion is able to trigger widespread landslides. In order to mitigate cascading hazards, we suggest that more effort should be placed in monitoring the upstream basin for early warnings. Engineering measures such as dams could be built in the middle basin to regulate the river discharge in order to prevent or reduce the water hazards.

\subsubsection{Education and training}

Public awareness of the hazards will help local communities to actively participate in hazard mitigation. Various education and training schemes should be explored to find a suitable system effective for the region with consideration on local culture, population, infrastructure and hazard types.

\subsection{Mitigating measures}

\subsubsection{Glacial lake outbursts and cascading disasters}

The integrated measures include the combination of monitoring, warning, engineering structures, and watershed management (Fig. 15): (a) for glacial lake outbursts, risk assessment on glacial lakes should be carried out. Monitoring and early warning systems should be developed. The observations should include temperature, precipitation, lake water level and video images. The information should be disseminated to the stakeholders in different countries (mainly China and Nepal for glacial lake outbursts); (b) for debris flows, engineering design standards should be modified to reflect the increased discharges from the glacial lake outbursts. Engineering structures such as bridges should be designed with long spans and no piers in the main valleys (e.g. for the 


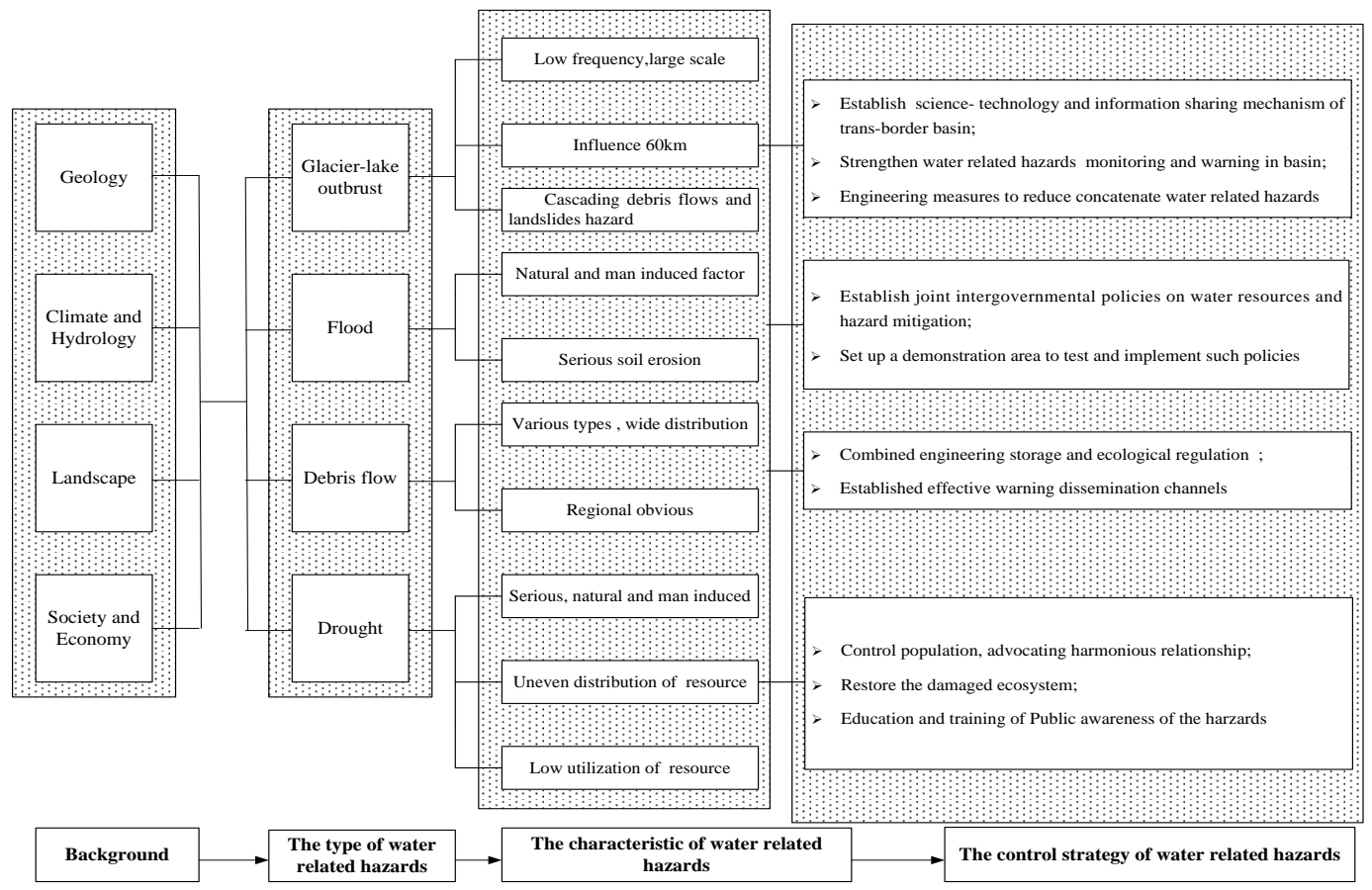

Fig. 14. Mitigating strategies for the Kosi River water hazards.

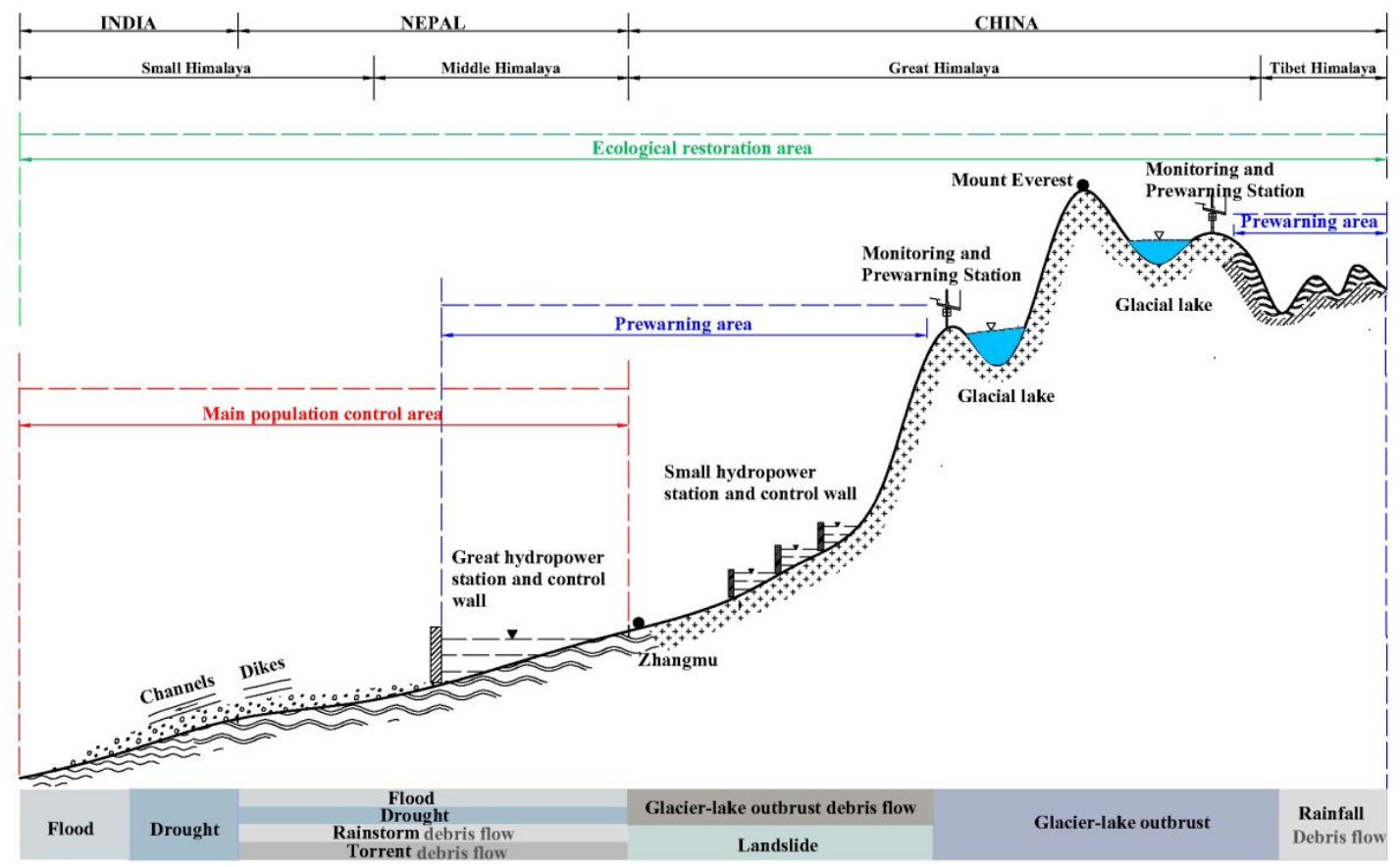

Fig. 15. Mitigating measures for the Kosi River water hazards. 
Sino-Nepal 707 Bridge, its main span is $200 \mathrm{~m}$ ); (c) for landslides, since the floods from glacial lake outbursts erode the downstream slope foot, the lands above are disturbed to initiate landslides. Step dams should be constructed to ensure the slope stability and dams should be high enough to stand above the debris flow siltation.

\subsubsection{Storm flood induced debris flows}

Debris flows from storm floods are mainly distributed in the Himalayas at the upstream of the river basin and the Small Himalayas in the middle basin where clastic rocks and pebbles are well developed. The scales of those debris flows are mainly small or medium. Prevention and control methods should adapt to the regional characteristics of socioeconomic development and debris flows. They may include (a) in the Tibetan Himalayas with sparse population, debris flows from storm floods that are on small scales and could be treated with engineering measures. Non-engineering measures are complementary, (b) in the middle Kosi River basin, debris flows are more wide spread with different scales. The roads have been built with low standards against water hazards and many residents live in alluvial fans. Large boulders are visible in this area which could cause significant damages during debris flows. Mass education on water hazards should be carried out to increase the understanding of local residents on the early signs of imminent hazards. For concentrated populations (such as towns), engineering measures should be used to mitigate the hazard risks and non-engineering measures should be used to complement the engineering ones.

\subsubsection{Droughts}

Drought is concentrated in the middle and lower Kosi River basin. Since the population density is very high in those areas, the consequences of droughts are severe. Possible measures are (a) to construct cascade reservoirs to store water from wet seasons for use in dry seasons. The reservoirs should be of multiple purposes such as hydropower, irrigation, water supply, and (b) to control the rapid population increase and restore the damaged ecosystem. Water resource assessments should be carried out so that the population and water demand could be appropriately matched.

\subsubsection{Floods}

The flooding disaster is mainly concentrated in the downstream plains of the Kosi River. Currently, these embankments are of high standards. Siltation of the river is a major long-term problem. Mitigating measures include (a) to reduce upstream land soil erosion in order to reduce river siltation; (b) to increase monitoring of the real time river information so that hydraulic structures could be operated more effectively to ensure the efficient passing through of flood waters.

\section{Conclusions}

This paper describes water related hazards in the Kosi River basin through a comprehensive literature search and site investigations. Although the basin is only $71500 \mathrm{~km}^{2}$ in size, it has the largest elevation drop in the world and covers a broad spectrum of climates (from tropical, subtropical, temperate to frigid zones), soils and vegetation. It is a challenge for the existing earth system models to be applied here. It would be very interesting to test modern NWP (Numerical Weather Prediction) models in this region to check if the models could cope with this highly heterogeneous terrains. The multiple water hazards such as glacial lake outbursts, debris flows, landslides, floods, droughts, soil erosion and sedimentation are all challenging problems for science and engineering. Those hazards could be further exacerbated by the rapid population increase and climate change. Detailed quantitative analysis from the hydrometeorological and demographic data is needed to assess their contributions to the hazard change. Since the river passes through three nations with different socioeconomic development states, international collaboration in dealing with water hazards is crucial. We hope this paper will draw attention to this region from the international research community and stimulate more active research to deal with the aforementioned natural and anthropogenic problems.

Acknowledgements. The authors wish to thank the Bomi Geologic Hazard Observation and Research Station and the Chatara hydrological station for providing the statistical data. The paper is finished with the financial support of the international cooperation projects (Water management and hazard risk reduction related policy and institutional analysis in China for Kosi River Basin Management), the National Science \& Technology Pillar Program during the Eleventh Five-Year Plan Period of the Ministry of Science and Technology, China (No.2008BAB42B06), the External Cooperation Program of the Chinese Academy of Sciences (No. GJHZ0954), and Chinese Ministry of Water Conservation Special Fund for Public Welfare Industry Project (No. 200801032). We wish to acknowledge the editors in NHESS Editorial Office and anonymous reviewers for constructive comments, which helped us in improving the contents and presentation of the manuscript.

Edited by: H. Kreibich

Reviewed by: three anonymous referees

\section{References}

Arnborg, L.: Hydrology of the glacial river Austurfljot, Geogr. Ann., 36, 185-201, 1955.

Bajracharya, S. R. and Mool, P.: Glaciers, glacial lakes and glacial lake outburst floods in the Mount Everest region, Nepal, Ann. Glaciol., 50, 81-86, 2009.

Bhalme, H. N. and Mooley, D. A.: Large-Scale Droughts/Floods and Monsoon Circulation, Mon. Weather Rev., 108, 1197-1211, 1980. 
Bilham, R., Gaur, V. K., and Molnar, P.: Himalayan Seismic Hazard, Science, 293, 1442-1444, 2001.

Birol, E. and Das, S.: Estimating the value of improved wastewater treatment: The case of River Ganga, India, J. Environ. Manage., 91, 2163-2171, 2010.

Burbank, D. W., Blythe, A. E., Putkonen, J., Pratt-Sitaula, B., Gabet, E., Oskin, M., Barros, A., and Ojha, T. P.: Decoupling of erosion and precipitation in the Himalayas, Nature, 426, 652-655, 2003.

Che, T., Jin, R., Li, X., and Wu, L. Z.: Glacial Lakes Variation and the Potentially Dangerous Glacial Lakes in the Pumqu Basin of Tibet during the Last Two Decades, Journal of Glaciology and Geocryology, 26, 397-402, 2004 (in Chinese).

Chen, X. Q., Cui, P., Li, Y., Yang, Zh., and Qi, Y. Q.: Changes in glacial lakes and glaciers of post-1986 in the Poiqu River basin, Nyalam, Xizang (Tibet), Geomorphology, 88, 298-311, 2007.

Church, M.: Baffin Island sandurs - A study of Arctic fluvial processes, Geological Society of Canada, Bulletin, 216, 208 pp., 1972.

Clague, J. J. and Mathews, W. H.: The magnitude of jokulhaups, J. Glaciol., 12, 501-504, 1973.

Clarke, G. K. C.: Glacier outburst floods from "Hazard Lake", Yukon Territory, and the problem of flood magnitude prediction, J. Glaciol., 28, 3-21, 1982.

Ding, Y. and Liu, J.: Glacial lake outburst flood disasters in China, Ann. Glaciol., 16, 180-184, 1992.

Dixit, A.: Kosi Embankment Breach in Nepal: Need for a Paradigm Shift in Responding to Floods, Econ. Polit. Weekly, 7, 70-78, 2009.

Fan, J. H., Wu, C. Y., and Cheng, G. W.: Distribution Characteristics and Influencing Factors of Geological Hazards in Tibet, Wuhan University Journal of Natural Sciences, 11, 806-812, 2006.

Gleick, P. H.: Global freshwater resources: soft-path solutions for the 21st century, Science, 302, 1524-1528, 2003.

Haeberli, W.: Frequency and characteristics of glacier floods in the Swiss Alps, Ann. Glaciol., 4, 85-90, 1983.

Ives, J. D.: Glacial lake outburst floods and risk engineering in the Himalaya, ICIMOD Occasional, 5, p. 42, 1986.

Liu, C. H. and Sharma, C. K.: Report on First Expedition to Glaciers and Glacier Lakes in the Pumqu (Arun) and Poiqu (Bhote-Sun Kosi) River basins, Xizang (Tibet), China, Science Press, Beijing, 1-192, 1988.

Liu, W.: Preliminary study on debris flow induced by glacier lake outburst in Tibet, Hydrogeology and Engineering Geology, 3, 88-92, 2006 (in Chinese).

Lü, R. R., Tang, B. X., and Li, D. J.: Debris Flow and Environment in Tibet, Sichuan University Press, Chengdu, 69-105, 1999 (in Chinese).

Meon, G. and Schwahz, W.: Estimation of Glacier Lake Outburst Flood and its Impact on a Hydro Project in Nepal, Snow and Glacier Hydrology, 218, 331-339, 1992.

Mool, P. K.: Glacier lake outburst floods in Nepal, Journal of Nepal Geological Society, 11, 273-280, 1995.
Mool, P. K., Bajracharya, S. R., and Joshi, S. P.: Inventory of glaciers, glacial lakes, and glacial lake outburst floods: Monitoring and early warning systems in the Hindu Kush-Himalayan region - Nepal, Kathmandu: ICIMOD, 365 pp., 2001.

Owen, L. A.: Shaping the Himalayas, Geographical Magazine, 12, 23-25, 1995.

Rajiv, S. and Sujit, S.: Climate-induced variability in the Late Pleistocene-Holocene fluvial and fluvio-deltaic successions in the Ganga plains, India: A synthesis, Geomorphology, 113, 173188, 2009.

Ramaswamy, R. I.: Floods, Himalayan Rivers, Nepal: Some Heresies, Econ. Polit. Weekly, 15, 37-40, 2008.

Ran, D. Ch., Luo, Q. H., Liu, B., and Wang, H.: Effect of soilretaining dams on flood and sediment reduction in middle reaches of Yellow River, SHUILI XUEBAO, 5, 7-14, 2004 (in Chinese).

Rashmi, K. Sh., Rhodante, A., Marloes,B., and Joyeeta, G.: Institutional Dysfunction and Challenges in Flood Control: A Case Study of the Kosi Flood 2008, Econ. Polit. Weekly, 2, 45-53, 2010.

Reynolds, J. M.: Glacial-lake outburst floods (GLOFs) in the Himalayas: an example of hazard mitigation from Nepal, Geoscience and Development, 2, 6-8, 1995.

Reynolds, J. M.: Glacial hazards in the Himalayas: an overview [abstract], Journal of Nepal Geological Society, 20, p. 255, 1999.

Richardson, S. D. and Reynolds, J. M.: An overview of glacial hazards in the Himalayas, Quatern. Int., 65/66, 31-47, 2000.

Sharma, C. K.: Partial drought conditions in Nepal, Hydrological Sciences Bulletin des Sciences Hydrologiques, 24, 327-334, 1979.

Shroder Jr., J. F.: Hazards of the Himalaya, Am. Sci., 77, 564-573, 1989.

Sinha, R., Tandon, S. K., Gibling, M. R., Bhattacharjee, P. S., and Dasgupta, A. S.: Late Quaternary geology and alluvial stratigraphy of the Ganga basin, Himal. Geol., 26, 223-240, 2005.

Stone, K. H.: The annual emptying of Lake George, Alaska: Arctic, 16, 26-40, 1963.

Whalley, W. B.: Observations of the drainage of an ice-dammed lake Strupvatnet, Troms, Norwaym, Norsk Geografisk Tidsekritt, 25, 165-174, 1971.

Xu, D. M.: Characteristics of Debris Flow Caused by Outburst of Glacial Lake in Boqu River, Xizang, China, 1981, GeoJournal, 17, 569-580, 1985.

Xue, X., Guo, J., Han, B. Sh., Sun, Q. W., and Liu, L. Ch.: The effect of climate warming and permafrost thaw on desertification in the Qinghai-Tibetan Plateau, Geomorphology, 108, 182-190, 2009.

Yamada, T.: Preliminary work report on glacier lake outburst flood in the Nepal Himalayas, WECS Report No. 4/1/291191/1/1 Seq., No. 387, 1991.

Yamada, T. and Sharma, C. K.: Glacier Lakes and Outburst Floods In the Nepal Himalaya, Snow and Glacier Hydrology, 28, 319330, 1993. 